Article

\title{
[Bis(Trimethylsilyl)Methyl]Lithium and -Sodium: Solubility in Alkanes and Complexes with O- and N- Donor Ligands
}

\author{
Markus von Pilgrim, Mihail Mondeshki and Jan Klett* \\ Institut für Anorganische Chemie und Analytische Chemie, Johannes Gutenberg-Universität Mainz, \\ Duesbergweg 10-14, 55128 Mainz, Germany; pillipower@gmx.de (M.v.P.); mondeshk@uni-mainz.de (M.M.) \\ * Correspondence: klettj@uni-mainz.de; Tel.: +49-6131-25256
}

Academic Editor: Matthias Westerhausen

Received: 9 May 2017; Accepted: 6 June 2017; Published: 12 June 2017

\begin{abstract}
In contrast to alkyl compounds of lithium, which play an important role in organometallic chemistry, the corresponding heavier alkali metal compounds are less investigated. These compounds are mostly insoluble in inert solvents or undergo solvolysis in coordinating solvents due to their high reactivity. An exception from this typical behavior is demonstrated by bis(trimethylsilyl) methylsodium. This study examines alkane solutions of bis(trimethylsilyl)methyllithium and -sodium by NMR spectroscopic and cryoscopic methods. In addition, structural studies by X-ray crystallography of the corresponding compounds coordinated by $\mathrm{O}$ - and $\mathrm{N}$ - ligands (tetrahydrofuran and tetramethylethylenediamine) present possible structural motifs of the uncoordinated compounds in solution.
\end{abstract}

Keywords: lithium; sodium; alkali metals; organometallic; alkyl; NMR spectroscopy; X-ray diffraction; cryoscopy; aggregation

\section{Introduction}

Alkyl compounds of lithium play an important role in organometallic chemistry [1-5]. This group of compounds is therefore well investigated, which can also be attributed to their accessibility and solubility in a wide range of organic solvents. It was shown that the reactivity of lithium alkyl compounds depends on the degree of aggregation in solution [6]. However, the dependency between aggregation and reactivity is not trivial, as it was shown for complexes of alkyllithium coordinated by tetramethylethylenediamine (TMEDA) [7]. Corresponding heavier alkali metal compounds, despite their high reactivity, play a considerable less prominent role. The large majority of these compounds show a poor solubility in some inert solvents and a destructive reactivity in other coordinating solvents [8]. An exemption from this trend can be observed for alkali metal compounds of bis(trimethylsilyl)methane, which allow the formation and isolation of a wide range of organometallic compounds [9]. A reaction of bis(trimethylsilyl)methyllithium [ $\left.\mathrm{LiCH}\left(\mathrm{SiMe}_{3}\right)_{2}\right], \mathbf{1}$ [10], with sodium tert-butoxide [ $\mathrm{NaO} t \mathrm{Bu}$ ] produces bis(trimethylsilyl)methylsodium $\left[\mathrm{NaCH}\left(\mathrm{SiMe}_{3}\right)_{2}\right], 2$, which is highly soluble in alkanes [11]. Another example of a soluble alkylsodium compound is 2-ethylhexylsodium, which was formed by direct synthesis and characterized in solution by ${ }^{1} \mathrm{H}-$ and ${ }^{23} \mathrm{Na}$-NMR spectroscopy [12]. However, X-ray crystal structure determination of 2 showed polymeric chains of $\left[\mathrm{NaCH}\left(\mathrm{SiMe}_{3}\right)_{2}\right]_{\infty}$ in the solid state (Scheme 1). Compound $\mathbf{1}$ also forms polymeric chains in the solid state; the sublimed compound in the gas-phase was determined as monomeric by electron diffraction [10] (for CSD refcodes see Appendix A). The corresponding potassium compound $\left[\mathrm{KCH}\left(\mathrm{SiMe}_{3}\right)_{2}\right]$ is insoluble in alkanes, but it is possible to isolate its complexes with tetrahydrofuran (THF) [13], tert-butyl methyl ether ( $t$ BuOMe), and pentamethyldiethylenetriamine (PMDETA) [14] 
in crystalline form. X-ray diffraction revealed their structures as THF and $t \mathrm{BuOMe}$ coordinated chain-polymers $\left[\mathrm{THF}-\mathrm{KCH}\left(\mathrm{SiMe}_{3}\right)_{2}\right]_{\infty}$ and $\left[t \mathrm{BuOMe}-\mathrm{KCH}\left(\mathrm{SiMe}_{3}\right)_{2}\right]_{\infty}$, and as a PMDETA coordinated (half-open) tetramer [PMDETA-KCH(SiMe $\left.)_{2}\right]_{4}$-PMDETA].

It is unlikely that the polymeric structure of $\mathbf{1}$ or $\mathbf{2}$ is maintained in solution, so lower aggregates such as dimers, trimers, tetramers, or hexamers should be present. Similar observations were made for a range of other alkyllithium compounds in solution [15]. 1 also forms polymeric chains in solid state, but monomeric units are found in gas-phase [10]. Complexes formed by coordination of $\mathbf{1}$ with TMEDA or PMDETA were also isolated (1-TMEDA (1) and 1-PMDETA), and the solid state structure of 1-PMDETA revealed monomeric units [16]. The understanding of the solution behavior of alkali metal alkyl compounds will allow insights into more complicated systems such as Lochmann-Schlosser superbases $[17,18]$. Recently, we reported the preparation of neopentyl potassium $\left[\mathrm{KCH}_{2} \mathrm{tBu}\right]$, which small but existing solubility allowed us to identify corresponding mixed lithium/potassium neopentyl/tert-butoxide aggregates [19] with possible relevance for such superbasic systems. The similarities between $\mathbf{1}$ and $\mathbf{2}$ encouraged us to investigate both compounds in solution by a comparative study using NMR spectroscopic and cryoscopic methods, allowing a better understanding of why both $\mathbf{1}$ and $\mathbf{2}$ show such good solubility in non-coordinating alkanes. In addition, we examined THF and TMEDA complexes of both $\mathbf{1}$ and $\mathbf{2}$ to learn more about the structural motifs found both in the pure and the coordinated compounds.
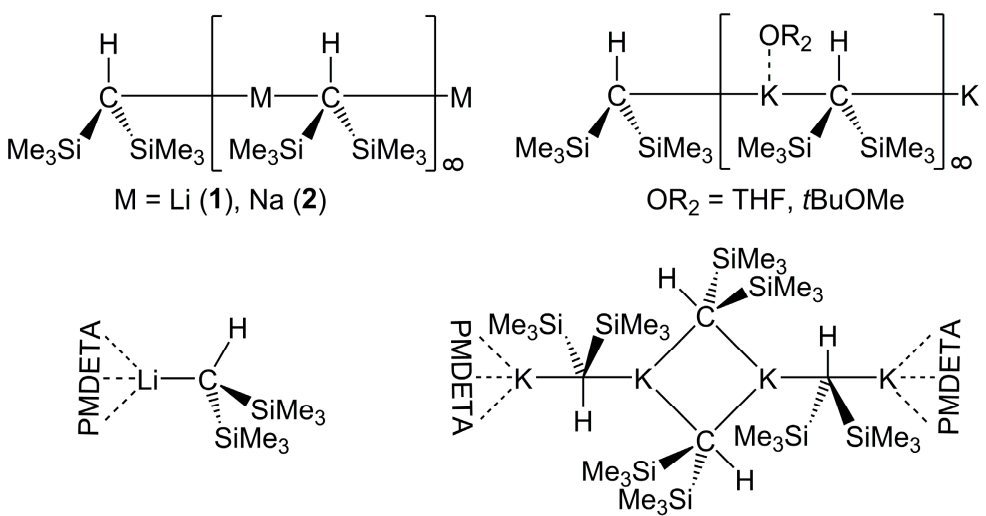

Scheme 1. Solid state structures of polymeric chains of compounds 1 [10], 2 [11] (top left), polymeric chains of $\mathrm{KCH}_{2}\left(\mathrm{SiMe}_{3}\right)_{2}-\mathrm{THF}$ and $\mathrm{KCH}_{2}\left(\mathrm{SiMe}_{3}\right)_{2}$-(tBuOMe) [13] (top right), monomeric 1-PMDETA [16] (bottom left), and (half-open) tetrameric $\mathrm{KCH}_{2}\left(\mathrm{SiMe}_{3}\right)_{2}$-PMDETA [14] (bottom right).

\section{Results and Discussion}

\subsection{Bis(Trimethylsilyl)Methyllithium $\mathbf{1}$ and -Sodium $\mathbf{2}$ in Solution}

The preparation of alkyl compounds of heavier alkali metal compounds often follows a similar protocol. By mixing an alkoxide of the corresponding alkali metal with an alkyllithium compound in $n$-hexane, the immediately formed insoluble alkyl compound can be isolated by filtration [8]. The preparation for $\mathbf{2}$ stands out, because no precipitate is formed, and the alkyl sodium compound is isolated by crystallization at $-30{ }^{\circ} \mathrm{C}$ from hexane [11]. This unusual high solubility in the non-coordinating solvent should be caused by breaking of the polymeric chain found in solid state into more mobile molecular units. To obtain information about the molecular weight and aggregation degree of these molecular units, we tested solutions of 1 and 2 by cryoscopic and NMR-DOSY methods. Cryoscopic measurements under inert gas conditions were performed in cyclohexane, which combines minimal to non-existent Lewis basicity (and therefore no coordinating abilities) and a considerable high cryoscopic constant with a freezing point at a convenient temperature $\left(6.7^{\circ} \mathrm{C}\right)$ [20]. This allows measurements with higher concentrations with comparatively high depression of the observed melting points (Table 1 and Table S1). The freezing point depression of $\mathbf{1}$ was measured 
only at one concentration $(0.04 \mathrm{~mol} / \mathrm{L})$ due to its low solubility in cyclohexane at this temperature. We observed a freezing point depression of 0.50 degrees, which corresponds to a molecular weight of $345 \mathrm{~g} / \mathrm{mol}$. This result points to the existence of dimeric units (open or ring-shaped dimers) in solution $(2 \times 166 \mathrm{~g} / \mathrm{mol}=332 \mathrm{~g} / \mathrm{mol}, \Delta \mathrm{M}=+3.7 \%)$. The comparable high solubility of 2 at $\sim 6{ }^{\circ} \mathrm{C}$ allowed us to study its solubility in cyclohexane in a range of concentrations $(0.021,0.041$, and $0.087 \mathrm{~mol} / \mathrm{L}$, see Table 1). The results at 0.021 and $0.041 \mathrm{~mol} / \mathrm{L}$ point to the existence of tetrameric units, while measurements at the higher concentrations of $0.087 \mathrm{~mol} / \mathrm{L}$ reveal higher molecular weights consistent with the presence of hexameric units. Cryoscopic measurements of trimethylsilylmethyllithium $\left[\mathrm{LiCH}_{2} \mathrm{SiMe}_{3}\right.$ ] in cyclohexane revealed a very similar behavior; depending on the concentration, it was possible to identify tetrameric or hexameric oligomers [15]. For geometric reasons, only even-numbered oligomers (dimer, tetramer, and hexamer) are considered. For tetramers and hexamers, the most likely arrangements are cages, such as face-capped tetra- or octahedrons. The basic elements of these cages are dimeric units, which can form higher oligomers following a principle called "ring-laddering" [21,22]. For this reason, the appearance of pentameric units is unlikely. However, the formation of ring-shaped trimers is possible but rarely observed for unsolvated organolithium compounds and more commonly for secondary lithium amides [23].

Table 1. Results of cryoscopic measurements of compounds $\mathbf{1}$ and $\mathbf{2}$ in cyclohexane. M(1-monomer) $166.34 \mathrm{~g} / \mathrm{mol}$; M(1-dimer) $332.68 \mathrm{~g} / \mathrm{mol}$; M(2-monomer) $182.39 \mathrm{~g} / \mathrm{mol}$; M(2-dimer) $364.76 \mathrm{~g} / \mathrm{mol}$; $\mathrm{M}(2$-tetramer) $729.52 \mathrm{~g} / \mathrm{mol}$; $\mathrm{M}(2$-hexamer) $1094.28 \mathrm{~g} / \mathrm{mol}$. Values of $\Delta \mathrm{T}[\mathrm{K}]$ are relative to the melting point of cyclohexane at $6.72{ }^{\circ} \mathrm{C}$, which was determined as a reference before each experiment.

\begin{tabular}{cccccc}
\hline Entry & Concentration $(\mathbf{m o l} / \mathbf{L})$ & $\boldsymbol{\Delta} \mathbf{T}(\mathbf{K})$ & $\mathbf{M}(\mathbf{E x p})(\mathrm{g} / \mathbf{m o l})$ & $\mathbf{M}$ (Oligomer) $(\mathrm{g} / \mathbf{m o l})$ & $\Delta \mathbf{M}$ \\
\hline Li-1 & 0.040 & -0.50 & 345 & 332.68 (1-dimer) & $+3.7 \%$ \\
$\mathrm{Na}-1$ & 0.021 & -0.12 & 804 & 729.52 (2-tetramer) & $+10.2 \%$ \\
$\mathrm{Na}-2$ & 0.041 & -0.29 & 663 & 729.52 (2-tetramer) & $-9.1 \%$ \\
$\mathrm{Na}-3$ & 0.087 & -0.35 & 1175 & 1094.28 (2-hexamer) & $+7.4 \%$ \\
$\mathrm{Na}-4$ & 0.087 & -0.37 & 1098 & 1094.28 (2-hexamer) & $+0.3 \%$ \\
\hline
\end{tabular}

Additionally, we studied solutions of 1 and 2 by NMR spectroscopy (Figures S1-S21). Measurements in solvents with different coordinating abilities can reveal influences on the corresponding aggregation behavior [24]. However, the results obtained by ${ }^{1} \mathrm{H},{ }^{13} \mathrm{C},{ }^{29} \mathrm{Si}$, and ${ }^{7} \mathrm{Li} \mathrm{NMR}$ spectroscopy in deuterated benzene $\left[\mathrm{C}_{6} \mathrm{D}_{6}\right]$, deuterated tetrahydrofuran [D8]THF, and deuterated cyclohexane $\left[\mathrm{C}_{6} \mathrm{D}_{12}\right]$ did not reveal significant differences such as changes in chemical shifts or splitting of signals (Table 2).

Table 2. ${ }^{1} \mathrm{H},{ }^{13} \mathrm{C},{ }^{29} \mathrm{Si}$, and ${ }^{7} \mathrm{Li} \mathrm{NMR}$ spectroscopic data of compounds $\mathbf{1}$ and $\mathbf{2}$ dissolved in $\mathrm{C}_{6} \mathrm{D}_{6}$, [D8]THF, and $\mathrm{C}_{6} \mathrm{D}_{12}$. The chemical shifts are given in ppm.

\begin{tabular}{|c|c|c|c|c|c|c|}
\hline \multirow{2}{*}{ Compound in Solvent } & \multicolumn{2}{|c|}{${ }^{1} \mathbf{H}$} & \multicolumn{2}{|c|}{${ }^{13} \mathrm{C}$} & \multirow{2}{*}{$\begin{array}{c}{ }^{29} \mathrm{Si} \\
\mathrm{SiMe}_{3}\end{array}$} & \multirow{2}{*}{${ }^{7} \mathrm{Li}$} \\
\hline & $\mathrm{SiMe}_{3}$ & $\mathrm{CH}_{2}$ & $\mathrm{SiMe}_{3}$ & $\mathrm{CH}_{2}$ & & \\
\hline 1 in $\mathrm{C}_{6} \mathrm{D}_{6}$ & 0.15 & -2.52 & 5.1 & 2.4 & -6.6 & 2.2 \\
\hline 1 in [D8]THF & -0.14 & -2.26 & 6.6 & 0.4 & -8.3 & 1.0 \\
\hline 1 in $C_{6} D_{12}$ & 0.05 & -2.29 & 4.8 & 3.4 & -7.9 & 3.6 \\
\hline 2 in $\mathrm{C}_{6} \mathrm{D}_{6}[11]$ & 0.20 & -2.04 & 7.0 & 0.4 & 12.4 & - \\
\hline 2 in $\mathrm{C}_{6} \mathrm{D}_{6}$ & 0.22 & -2.01 & 7.0 & 0.0 & -11.8 & - \\
\hline 2 in [D8]THF & -0.16 & -2.09 & 6.9 & -0.4 & -11.3 & - \\
\hline 2 in $C_{6} D_{12}$ & 0.04 & -2.08 & 7.1 & -0.1 & -12.1 & - \\
\hline
\end{tabular}

To obtain additional information about the degree of aggregation in non-coordinating solvents parallel to the results obtained by cryoscopic measurements (see above), we carried out ${ }^{1} \mathrm{H}$ diffusion ordered spectroscopy (DOSY) NMR [25] at $21^{\circ} \mathrm{C}$ to study the oligomer formation as a function of the concentration (Table 3 ) in deuterated cyclohexane $\left[\mathrm{C}_{6} \mathrm{D}_{12}\right]$ solutions of two organometallic compounds $\mathbf{1}\left[\mathrm{LiCH}\left(\mathrm{SiMe}_{3}\right)_{2}\right]$ and $\mathbf{2}\left[\mathrm{NaCH}\left(\mathrm{SiMe}_{3}\right)_{2}\right]$. Considering the basic properties of the compounds, inert 
tetrakis(trimethylsilyl)silane $\left[\mathrm{Si}\left(\mathrm{SiMe}_{3}\right)_{4}\right]$ at the same concentration as the investigated compounds for all samples was chosen as a reference. The $D$ values $\left(\mathrm{m}^{2} / \mathrm{s}\right)$ were acquired from the diffusion analyses, and the respective hydrodynamic radii were calculated using the Stokes-Einstein equation: $D=\left(k_{B} T\right) /\left(6 \pi \eta r_{\mathrm{H}}\right)$ where $k_{\mathrm{B}}$ is the Boltzmann constant, $\eta[\mathrm{kg} /(\mathrm{s} \cdot \mathrm{m})]$ is the viscosity of the solvent at the respective temperature $T(\mathrm{~K})$ and $r_{\mathrm{H}}$ the hydrodynamic radius in $\mathrm{nm}$ (for a spherical particle).

Table 3. Diffusion coefficients and calculated hydrodynamic radii for compounds $\mathbf{1}$ and $\mathbf{2}$ obtained from the ${ }^{1} \mathrm{H}$ DOSY NMR experiments in deuterated cyclohexane $\mathrm{C}_{6} \mathrm{D}_{12}$. Tetrakis(trimethylsilyl)silane $\mathrm{Si}\left(\mathrm{SiMe}_{3}\right)_{4}$ was used as a reference.

\begin{tabular}{cccccc}
\hline Compound & Conc (mol/L) & $\boldsymbol{D}\left(\mathbf{1 0}^{-\mathbf{1 0}} \mathbf{~ m}^{\mathbf{2}} \mathbf{s}\right)$ & $\boldsymbol{r}_{\mathbf{H}}(\mathbf{n m})$ & $\begin{array}{c}\boldsymbol{D}\left[\mathrm{Si}\left(\mathrm{SiMe}_{\mathbf{3}}\right)_{\mathbf{4}}\right] \\
\left(\mathbf{1 0}^{-\mathbf{1 0}} \mathbf{~ m}^{\mathbf{2}} \mathbf{s}\right)\end{array}$ & $\begin{array}{c}\boldsymbol{r}_{\mathbf{H}}\left[\mathrm{Si}\left(\mathrm{SiMe}_{\mathbf{3}}\right)_{4}\right] \\
(\mathbf{n m})\end{array}$ \\
\hline 1 & 0.08 & 6.258 & 0.33 & 5.828 & 0.35 \\
1 & 0.19 & 6.020 & 0.34 & 5.781 & 0.36 \\
1 & $<0.3^{1}$ & 5.243 & 0.39 & 5.998 & 0.34 \\
2 & 0.1 & 2.877 & 0.72 & 6.295 & 0.33 \\
2 & 0.2 & 2.355 & 0.88 & 5.959 & 0.35 \\
2 & $<0.3^{1}$ & 1.920 & 1.10 & 5.454 & 0.38 \\
\hline
\end{tabular}

${ }^{1}$ Saturated solutions.

Increasing the concentration of the solutions for both investigated compounds leads to a slight increase in the calculated value for the hydrodynamic radius of the reference $\mathrm{Si}\left(\mathrm{SiMe}_{3}\right)_{4}$ (on average $0.35 \mathrm{~nm}$ ), which is related to a somewhat slower diffusion (Figure 1). This variation is, however, minimal and probably due to more contact with other molecules in the solution at higher concentrations. In the solution of 2 with a $0.1 \mathrm{~mol} / \mathrm{L}$ concentration, the hydrodynamic radius is determined to be approximately twice as high compared to $\mathrm{Si}\left(\mathrm{SiMe}_{3}\right)_{4}(0.72 \mathrm{~nm}$ versus ca. $0.35 \mathrm{~nm})$. This fact most probably reflects the formation of a tetramer, especially considering the difference in the molecular masses $\left(182.39 \mathrm{~g} / \mathrm{mol}\right.$ for the base compared to $320.84 \mathrm{~g} / \mathrm{mol}$ for $\left.\mathrm{Si}\left(\mathrm{SiMe}_{3}\right)_{4}\right)$. Further stepwise increase of the solute concentration in $0.1 \mathrm{~mol} / \mathrm{L}$ steps (until saturation) results in slower diffusion, resp. noticeably higher $r_{\mathrm{H}}$ values for 2 . This we attribute to the formation of higher oligomers. It should be considered that the formation and dissociation of such complexes is fast on the NMR timescale, and the measured diffusion coefficients and the corresponding calculated hydrodynamic radii represent a weighted average of the present species in the mixture. Thus, we conclude that at a concentration of $0.2 \mathrm{~mol} / \mathrm{L}$ of $\mathrm{NaCH}\left(\mathrm{SiMe}_{3}\right)_{2}$, the maximum in the distribution of the formed oligomeric complexes is around 5 aggregated monomer units (a mixture of tetramers and hexamers), which corresponds to an average hydrodynamic radius of $0.88 \mathrm{~nm}$. A further increase in the concentration leads to a shift of this maximum to about $1.10 \mathrm{~nm}$, which is related to a predominant hexamer formation.

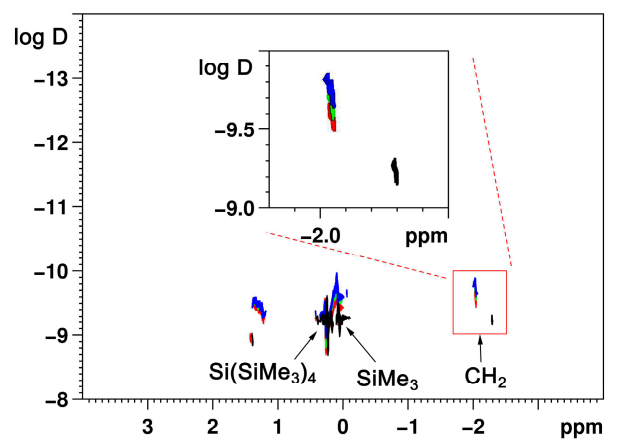

Figure 1. ${ }^{1} \mathrm{H}$ DOSY spectra of $\left(\mathrm{NaCH}\left(\mathrm{SiMe}_{3}\right)_{2}, 2,0.1 \mathrm{~mol} / \mathrm{L}\right.$-green, $0.2 \mathrm{~mol} / \mathrm{L}$-red, $0.3 \mathrm{~mol} / \mathrm{L}$-blue and $\mathrm{LiCH}\left(\mathrm{SiMe}_{3}\right)_{2}, \mathbf{1}, 0.079 \mathrm{~mol} / \mathrm{L}$-black) with the $\mathrm{CH}$ region magnified. Increasing the concentration of 1 (only the $0.079 \mathrm{~mol} / \mathrm{L}$ concentration spectrum presented) hardly influences the diffusion behavior of $\mathbf{1}$ as dimers are presumably formed in the solution. The constant change of the diffusion coefficient of 2 as a function of the concentration reflects the formation and growth of higher aggregates. 
In a parallel study, such a concentration-dependent complex growth was not detected for the solutions of 1 . At all measured concentrations, comparable $D$ and $r_{\mathrm{H}}$ values for the organometallic base and the $\mathrm{Si}\left(\mathrm{SiMe}_{3}\right)_{4}$ reference were observed (Table 3). Taking into account the molecular masses of both compounds $\left(166.34 \mathrm{~g} / \mathrm{mol}\right.$ for the $\mathrm{LiCH}\left(\mathrm{SiMe}_{3}\right)_{2}$ and $\left.320.84 \mathrm{~g} / \mathrm{mol} \mathrm{for} \mathrm{Si}\left(\mathrm{SiMe}_{3}\right)_{4}\right)$ as well as comparing with the hydrodynamic radii calculated for 2 , we conclude that a dimer is predominantly stabilized in all solutions of 1 with a corresponding $r_{\mathrm{H}}$ of $0.34 \mathrm{~nm}$. The slightly higher $r_{\mathrm{H}}$ value measured at saturation $(0.39 \mathrm{~nm})$ is most probably related to the sole amount of solute rather than with the formation of higher complexes, which, however, cannot be completely excluded. Thus, the NMR results are in good agreement with the cryoscopy measurements (Figure 2). The discrepancy between the cryoscopy and DOSY results for the concentrations of 2 resulting in hexamers can be attributed to temperature-dependent tendencies to form higher aggregates. The formation of higher aggregates of 2 seems to be thermodynamically favored, but at higher temperatures the lower aggregates are favored by entropy.

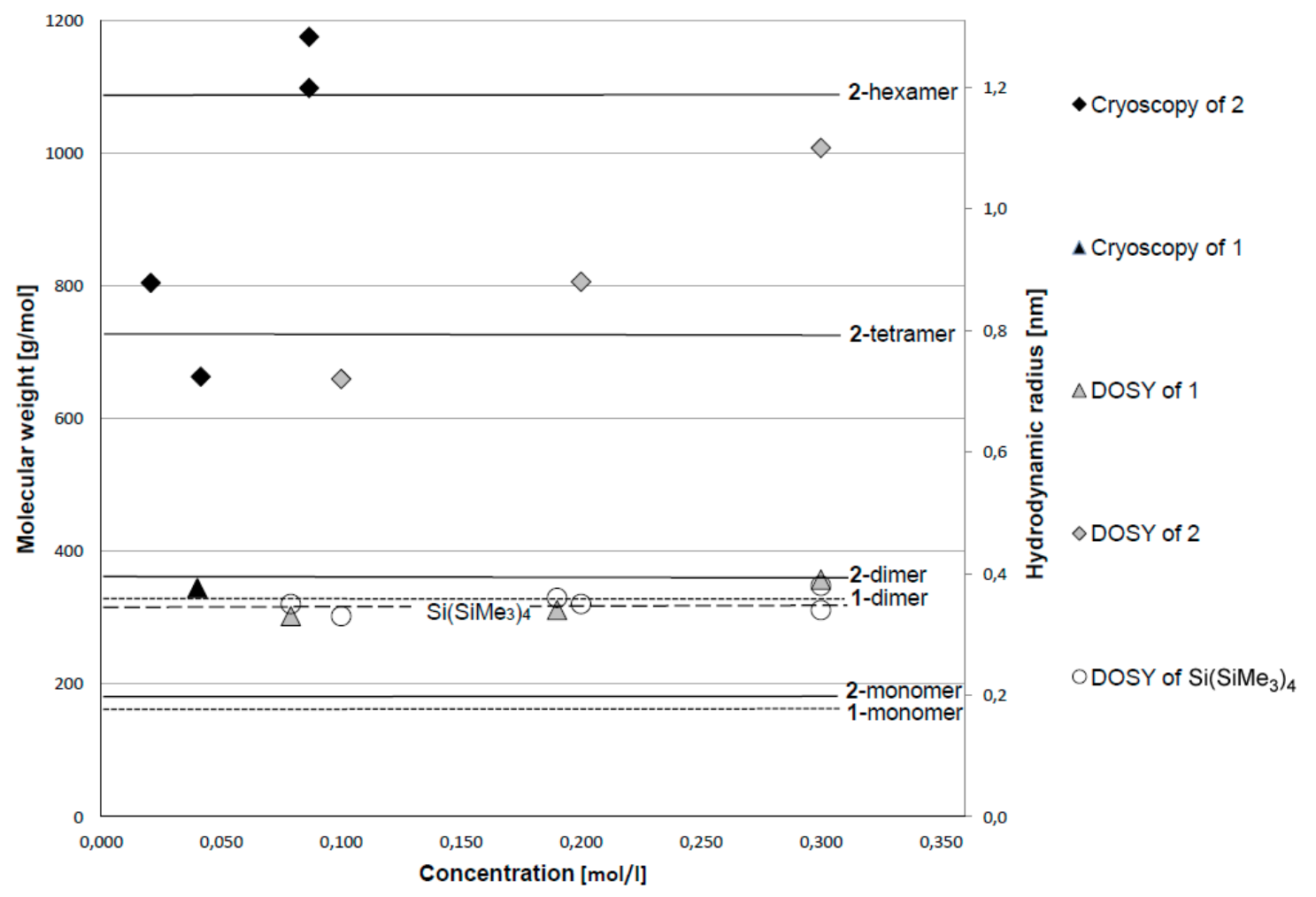

Figure 2. Graphical representation of the results of cryoscopic (at $6^{\circ} \mathrm{C}$ ) and NMR DOSY measurements (at $21^{\circ} \mathrm{C}$ ). Values for cryoscopic measurements in $[\mathrm{g} / \mathrm{mol}]$ for the molecular weight (left ordinate); the molecular weights of monomers/oligomers of $\mathbf{1}, \mathbf{2}$, and $\mathrm{Si}\left(\mathrm{SiMe}_{3}\right)_{4}$ are represented as horizontal lines (1: dotted line; 2 : solid line; $\mathrm{Si}\left(\mathrm{SiMe}_{3}\right)_{4}$, only monomeric: dashed line). Values for NMR DOSY measurements in [nm] for the hydrodynamic radius (right ordinate). Results for compound 1 shown as triangles (full: cryoscopy; open: DOSY); for compound 2 shown as diamonds (full: cryoscopy; open: DOSY). Values for DOSY measurements of reference compound $\mathrm{Si}\left(\mathrm{SiMe}_{3}\right)_{4}$ are added as open circles; the right ordinate is scaled to fit the corresponding hydrodynamic radius of $0.35 \mathrm{~nm}$ to the height of the molecular weight of $\mathrm{Si}\left(\mathrm{SiMe}_{3}\right)_{4}$ with $320.84 \mathrm{~g} / \mathrm{mol}$.

\subsection{Formation of Complexes of Compounds $\mathbf{1}$ and $\mathbf{2}$ with $\mathrm{O}$ - and $\mathrm{N}$ - Donors}

In order to obtain more data about possible structural motifs of $\mathbf{1}$ and $\mathbf{2}$ existing in solution, we studied complexes of $\mathbf{1}$ and $\mathbf{2}$ with THF or TMEDA in the solid state (Scheme 2). The metal atom of the alkali metal alkyl compound interacts with the carbon atoms through electron-deficient 2-electron-3-(or more)-center bonds. This makes the electrophile metal atom very susceptible to interactions with 
Lewis-basic ligands. The obtained structures may show structural motifs with relevance to monomeric, dimeric, or tetrameric units, due to the increased steric saturation of the coordination sphere of the metal atoms. At the same time, several possible coordination modes corresponding to metal atoms, such as linear bridging, angular bridging, or terminal coordination of the bis(trimethylsilyl)methyl groups (or metal atoms) can be studied.

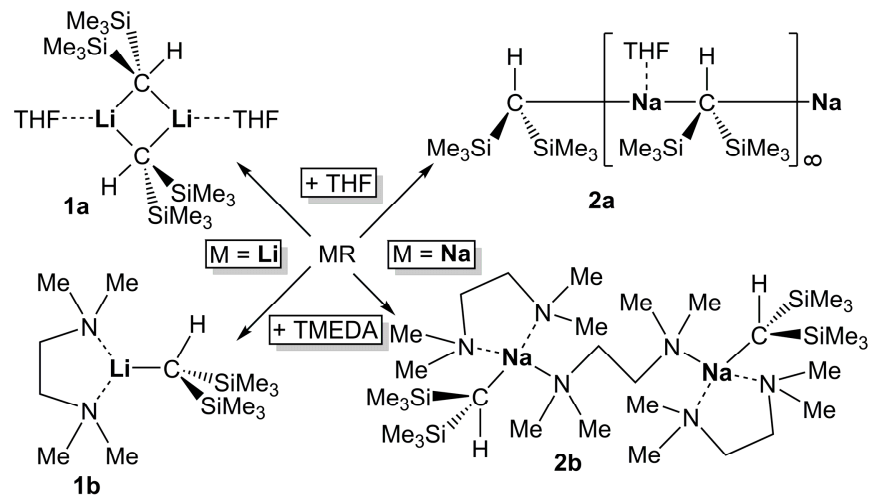

Scheme 2. Formation of compounds $\mathbf{1} \mathbf{a}, \mathbf{b}$ and $\mathbf{2} \mathbf{a}, \mathbf{b}$ by adding THF or TMEDA to solutions of the corresponding compounds $\mathbf{1}$ or $\mathbf{2}$ in $n$-hexane.

Treatment of solutions of $\mathbf{1}$ or $\mathbf{2}$ in $n$-hexane at RT with THF or TMEDA in equimolar amounts (1b) or excess $(\mathbf{1} \mathbf{a}, \mathbf{2} \mathbf{a}, \mathbf{b})$ produces clear solutions, from which colorless crystals can be obtained (1a at RT, 1b at $5{ }^{\circ} \mathrm{C}, \mathbf{2} \mathbf{a}, \mathbf{b}$ at $-20{ }^{\circ} \mathrm{C}$ ) with moderate to low yields (1a: $\left.52 \% ; \mathbf{1 b}: 34 \% ; \mathbf{2 a}: \mathbf{1 7 \%}, \mathbf{2 b}:<5 \%\right)$. The absence of decomposition (ether cleavage) in the case of the mixture of $\mathbf{1}$ and $\mathbf{2}$ with THF demonstrates the low reactivity of these bis(trimethylsilyl)methyl compounds towards THF in contrast to other lithium compounds such as neopentyllithium [24] or $t$-butyllithium [26]. Crystals of compound 2b easily decomposed or melted at RT. Lappert et al. already described and characterized solutions of compound $\mathbf{1 b}$ in cyclohexane as monomeric units [16]. However, a solid state structure was not reported.

\subsection{NMR-Spectroscopy of Complexes of Compounds 1 and 2 with $\mathrm{O}$ - and $\mathrm{N}$ - Donors}

The thermal stability and good solubility of compounds $\mathbf{1} \mathbf{a}, \mathbf{b}$ and $\mathbf{2} \mathbf{a}, \mathbf{b}$ allowed their characterization by NMR spectroscopy. To avoid any undesired metalation reactions or secondary coordination, the ${ }^{1} \mathrm{H},{ }^{13} \mathrm{C},{ }^{29} \mathrm{Si}$, and ${ }^{7} \mathrm{Li} \mathrm{NMR}$ spectra were recorded in deuterated cyclohexane $\left[\mathrm{C}_{6} \mathrm{D}_{12}\right]$ (Table 4 , Figures S22-S35).

Table 4. ${ }^{1} \mathrm{H},{ }^{13} \mathrm{C},{ }^{29} \mathrm{Si}$, and ${ }^{7} \mathrm{Li}$ NMR spectroscopic data of compounds $\mathbf{1} \mathbf{a}, \mathbf{b}$ and $\mathbf{2} \mathbf{a}, \mathbf{b}$ dissolved in $\mathrm{C}_{6} \mathrm{D}_{12}$. The corresponding data of compounds $\mathbf{1}$ and $\mathbf{2}$ are added for comparison. The ligand is THF or TMEDA, respectively. The chemical shifts are given in ppm.

\begin{tabular}{|c|c|c|c|c|c|c|c|c|}
\hline \multirow{2}{*}{ Compound } & \multicolumn{3}{|c|}{${ }^{1} \mathbf{H}$} & \multicolumn{3}{|c|}{${ }^{13} \mathrm{C}$} & \multirow{2}{*}{$\begin{array}{c}{ }^{29} \mathrm{Si} \\
\mathrm{SiMe}_{3}\end{array}$} & \multirow{2}{*}{${ }^{7} \mathrm{Li}$} \\
\hline & $\mathrm{SiMe}_{3}$ & $\mathrm{CH}_{2}$ & Ligand & $\mathrm{SiMe}_{3}$ & $\mathrm{CH}_{2}$ & Ligand & & \\
\hline 1 & 0.05 & -2.29 & - & 4.8 & 3.4 & - & -6.6 & 3.6 \\
\hline 1a & -0.02 & -2.39 & $\begin{array}{l}1.89\left(\beta-\mathrm{CH}_{2}\right) \\
3.88\left(\alpha-\mathrm{CH}_{2}\right)\end{array}$ & 5.7 & 2.0 & $\begin{array}{l}26.1\left(\beta-\mathrm{CH}_{2}\right) \\
69.2\left(\alpha-\mathrm{CH}_{2}\right)\end{array}$ & -6.0 & 2.9 \\
\hline $1 b$ & -0.10 & -2.05 & $\begin{array}{c}2.30(\mathrm{Me}) \\
2.37\left(\mathrm{CH}_{2}\right)\end{array}$ & 6.4 & 2.3 & $\begin{array}{c}45.9(\mathrm{Me}) \\
57.3\left(\mathrm{CH}_{2}\right)\end{array}$ & -7.9 & 3.1 \\
\hline 2 & 0.04 & -2.08 & - & 7.1 & -0.1 & - & -12.1 & - \\
\hline $2 a$ & 0.00 & -2.28 & $\begin{array}{l}1.83\left(\beta-\mathrm{CH}_{2}\right) \\
3.76\left(\alpha-\mathrm{CH}_{2}\right)\end{array}$ & 6.7 & 1.1 & $\begin{array}{l}27.0\left(\beta-\mathrm{CH}_{2}\right) \\
68.7\left(\alpha-\mathrm{CH}_{2}\right)\end{array}$ & -10.1 & - \\
\hline $2 b$ & -0.08 & -2.04 & $\begin{array}{c}2.25(\mathrm{Me}) \\
2.34\left(\mathrm{CH}_{2}\right)\end{array}$ & 6.7 & 1.0 & $\begin{array}{c}46.2(\mathrm{Me}) \\
58.0\left(\mathrm{CH}_{2}\right)\end{array}$ & -8.5 & - \\
\hline
\end{tabular}


The signal integrals in the ${ }^{1} \mathrm{H}$ NMR spectra of all four ligand-coordinated compounds $\mathbf{1 a}, \mathbf{b}$ and $\mathbf{2} \mathbf{a}, \mathbf{b}$ indicate corresponding equimolar ratios of the bis(trimethylsilyl)methyl compound to the coordinating ligand close to 1:1. The evacuation during the preparation of the NMR samples did not lead to the total loss of THF or TMEDA, which confirms the readiness of the metal atoms to accept additional interactions with such donor molecules.

\subsection{X-ray Crystallographic Measurements of Compounds $\mathbf{1 a}, \boldsymbol{b}$ and $\mathbf{2} \boldsymbol{a}, \boldsymbol{b}$}

All four compounds $\mathbf{1 a}, \mathbf{b}$ and $\mathbf{2} \mathbf{a}, \mathbf{b}$ crystallized in the same monoclinic space group (Table 5, Figures S36-S39). The thermal instability of single crystals of compounds $\mathbf{1} \mathbf{b}$ and $\mathbf{2} \mathbf{b}$ required sample preparation for X-ray crystallography at low temperatures [27]. The THF or TMEDA groups showed significant positional disorder in compounds $\mathbf{1 a}(0.53 / 0.47), \mathbf{1 b}(0.68 / 0.32$ and $0.75 / 0.25)$, and 2b $(0.78 / 0.22)$ [16]. In compound $\mathbf{1 b}$, one trimethylsilyl group displayed rotational disorder $(0.5 / 0.5)$. In all four compounds, it was possible to locate the hydrogen atom of the metal bound CH-group.

Table 5. Selected crystallographic data for compounds $\mathbf{1 a}, \mathbf{1 b}, \mathbf{2} \mathbf{a}$ and $\mathbf{2 b}{ }^{[a]}$.

\begin{tabular}{|c|c|c|c|c|}
\hline Compound & 1a & $1 b$ & $2 \mathbf{a}$ & $2 b$ \\
\hline Formula & $\mathrm{C}_{11} \mathrm{H}_{27} \mathrm{LiOSi}_{2}$ & $\mathrm{C}_{13} \mathrm{H}_{35} \mathrm{LiN}_{2} \mathrm{Si}_{2}$ & $\mathrm{C}_{11} \mathrm{H}_{27} \mathrm{NaOSi}_{2}$ & $\mathrm{C}_{16} \mathrm{H}_{43} \mathrm{NaN}_{3} \mathrm{Si}_{2}$ \\
\hline $\mathrm{M}_{r}\left(\mathrm{~g} \cdot \mathrm{mol}^{-1}\right)$ & 238.44 & 282.55 & 254.49 & 713.39 \\
\hline Crystal system & monoclinic & monoclinic & monoclinic & monoclinic \\
\hline Space group & $P 2_{1} / n$ & $P 2_{1} / c$ & $P 2_{1} / n$ & $P 2_{1} / n$ \\
\hline$a(\AA)$ & $9.4930(9)$ & $18.7636(8)$ & $11.3470(19)$ & $10.450(4)$ \\
\hline$b(\AA)$ & $9.9165(9)$ & $13.2303(5)$ & $9.7379(17)$ & $17.414(6)$ \\
\hline$c(\AA)$ & 16.7191(14) & $17.7299(7)$ & $14.622(2)$ & $14.258(5)$ \\
\hline$\alpha\left(^{\circ}\right)$ & 90 & 90 & 90 & 90 \\
\hline$\beta\left(^{\circ}\right)$ & $92.527(2)$ & $112.040(2)$ & $90.876(5)$ & $100.824(9)$ \\
\hline$\gamma\left({ }^{\circ}\right)$ & 90 & 90 & 90 & 90 \\
\hline$V\left(\AA^{3}\right)$ & $1572.4(3)$ & $4079.8(3)$ & $1615.5(5)$ & 2548.5(16) \\
\hline $\mathrm{Z}$ & 4 & 8 & 4 & 6 \\
\hline$\rho_{\text {calcd }}\left(\mathrm{g} \cdot \mathrm{cm}^{-3}\right)$ & 1.007 & 0.920 & 1.046 & 0.930 \\
\hline$\mu(\operatorname{Mo~} K \alpha)\left(\mathrm{mm}^{-1}\right)$ & 0.203 & 0.163 & 0.226 & 0.158 \\
\hline$T(\mathrm{~K})$ & 173 & 173 & 173 & 173 \\
\hline measured refl. ${ }^{[b]}$ & 51,345 & 51,744 & 17,850 & 37,556 \\
\hline independent refl. & 3766 & 9687 & 3904 & 6057 \\
\hline refined parameters & 192 & 183 & 141 & 236 \\
\hline$R 1^{[\mathrm{c}]}$ & 0.0320 & 0.0449 & 0.0690 & 0.0441 \\
\hline$R 1$, all data & 0.0428 & 0.1013 & 0.1539 & 0.0932 \\
\hline$w R 2^{[\mathrm{d}]}$ & 0.0898 & 0.0964 & 0.1572 & 0.1034 \\
\hline$w R 2$, all data & 0.0964 & 0.1112 & 0.1894 & 0.1196 \\
\hline $\max$, min peaks $\left(\mathrm{e}^{-3}\right)$ & $0.369,-0.161$ & $0.270,-0.187$ & $0.910,-0.510$ & $0.265,-0.203$ \\
\hline CCDC numbers [28] & $1,548,189$ & $1,548,191$ & $1,548,190$ & $15,481,892$ \\
\hline
\end{tabular}

[a] All data were collected using Mo $K \alpha$ radiation $\left(\lambda=0.71073 \AA\right.$ ). ${ }^{[b]}$ Observation criterion: $I>2 \sigma(I)$.

${ }^{[\mathrm{c}]} R 1=\Sigma|| F_{o}|-| F_{c}|| / \Sigma\left|F_{o}\right| .{ }^{[\mathrm{d}]} w R 2=\left\{\Sigma\left[w\left(F_{o}{ }^{2}-F_{c}{ }^{2}\right)^{2}\right] / \Sigma\left[w\left(F_{o}{ }^{2}\right)^{2}\right]\right\}^{1 / 2}$.

Compound 1a (Figure 3) is a dimer formed by two THF-coordinated 1-units (Table 6). The central motif is a planar $\mathrm{Li}_{2} \mathrm{C}_{2}$ ring with crystallographic inversion symmetry. This motif is similar to the THF-coordinated lithium bis(trimethylsilyl)amide, where the bis(trimethylsilyl)methyl group is replaced by the isoelectronic bis(trimethylsilyl)amide [29]. The $\mathrm{Li}_{2} \mathrm{C}_{2}$ ring has one shorter (2.204(2) $\AA$ ) and one longer $(2.274(3) \AA) \mathrm{Li}-\mathrm{C}$ bond, and the $\mathrm{C}-\mathrm{Li}-\mathrm{C}$ angle $\left(115.36(10)^{\circ}\right)$ is far wider than the corresponding Li-C-Li angle $\left(64.64(10)^{\circ}\right)$. The trigonal pyramidal bis(trimethylsilyl)methyl unit (sum of the Si-C-Si and two H-C-Si angles: $327.2^{\circ}$ ) leads to an orientation of both trimethylsilyl groups above and below, and the corresponding hydrogen atom roughly in the plane of the central $\mathrm{Li}_{2} \mathrm{C}_{2}$ ring. The lithium atom with a coordination number of $\mathrm{CN}=3$ shows an additional coordination of the oxygen atom of the THF group (Li-O 1.953(8) $\AA$ ), leading to an approximate trigonal planar arrangement $\left(\mathrm{C}-\mathrm{Li}-\mathrm{O} 137.4(7)^{\circ}\right.$ and $\left.110.5(6)^{\circ}\right)$. 


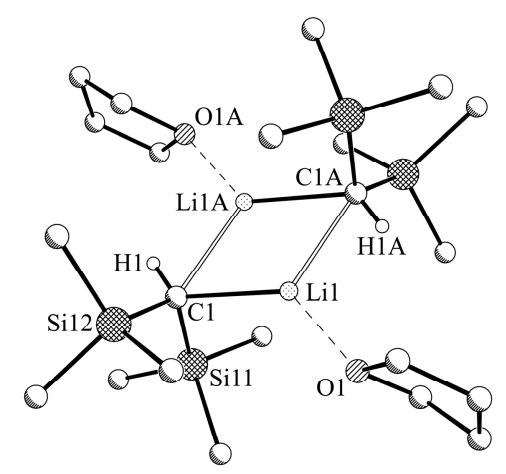

Figure 3. Molecular structure of $\mathrm{LiCH}\left(\mathrm{SiMe}_{3}\right)_{2}-\mathrm{THF}$, 1a. Selected hydrogen atoms and disordered units of minor occupancy are omitted for clarity. Symmetry operator A: $-x,-y$ and $-z$.

Table 6. Selected bond lengths $(\AA)$ and angles $\left(^{\circ}\right)$ of compounds $\mathbf{1} \mathbf{a}, \mathbf{b}$ and $\mathbf{2 a}, \mathbf{b}$.

\begin{tabular}{|c|c|c|c|c|}
\hline Compound & 1a $(\mathrm{M}=\mathrm{Li})$ & $1 b(M=L i)$ & $2 \mathrm{a}(\mathrm{M}=\mathrm{Na})$ & $2 b(M=N a)$ \\
\hline M1-C1 & $2.204(2)$ & $2.070(3) / 2.083(3)$ & $2.778(4)$ & $2.520(2)$ \\
\hline M1-C1A & $2.274(3)$ & - & $2.657(4)$ & - \\
\hline M1-O1 & $1.953(8)$ & - & $2.375(3)$ & - \\
\hline M1-N21 & - & - & - & $2.559(2)$ \\
\hline M1-N22 & - & - & - & $2.569(2)$ \\
\hline M1-N31 & - & $2.054(6) / 2.133(7)$ & - & $2.635(2)$ \\
\hline M1-N32 & - & $2.071(9) / 2.061(9)$ & - & - \\
\hline C1-Si11 & $1.835(2)$ & $1.809(2) / 1.813(2)$ & $1.809(5)$ & $1.808(2)$ \\
\hline C1-Si12 & $1.838(2)$ & $1.807(2) / 1.803(2)$ & $1.800(5)$ & $1.808(2)$ \\
\hline M1-M1A & $2.395(4)$ & - & - & - \\
\hline M1-H1 & 2.81 & $2.30 / 2.43$ & $2.68 / 2.70$ & 2.71 \\
\hline M1-C1-M1A & $64.64(10)$ & - & $159.30(18)$ & - \\
\hline C1-M1-C1A & $115.36(10)$ & - & $130.74(6)$ & - \\
\hline C1-M1-O1 & $137.4(7)$ & - & 129.93(13) & - \\
\hline C1A-M1-O1 & $110.5(6)$ & - & $99.33(13)$ & - \\
\hline Si11-C1-Si12 & $117.06(7)$ & $123.25(10) / 122.48(11)$ & $127.9(3)$ & 120.91 \\
\hline$\Sigma \mathrm{CHSi}_{2}$ & 327.2 & $341.1 / 341.0$ & 359.3 & 336.0 \\
\hline
\end{tabular}

X-ray crystallography as well as NMR spectroscopy revealed compound $\mathbf{1 b}$ (Figure 4) as a monomeric TMEDA-coordinated bis(trimethylsilyl)methyllithium with one TMEDA molecule per lithium atom, similar to the corresponding monomeric complex 1-PMDETA [16]. Two crystallographically independent units are found in the monoclinic cell. The distance between the lithium atoms (both with a coordination number of $\mathrm{CN}=3$ ) and the carbon of the central carbon atom of the bis(trimethylsilyl)methyl group Li-C is 2.070(3)/2.083(3) $\AA$ shorter than the corresponding distances in polymeric $\mathbf{1}$ (2.14 to $2.22 \AA$ ) [10] or dimeric $1 \mathrm{a}$ (2.204(2) $\AA$ ). On the other hand, the Li-C distance for evaporated 1 determined by gas-phase electron diffraction is with $2.03 \AA$ shorter [10]; in monomeric 1-PMDETA, the $\mathrm{Li}-\mathrm{C}$ distance is $2.14 \AA$ [16]. The similar results for both monomeric $\mathbf{1 b}$ (1-TMEDA) and 1-PMDETA with a considerable difference in the steric demand of the corresponding ligand demonstrate the spacial flexibility of the bis(trimethylsilyl)methyl group, which makes it such a useful ligand in the formation of otherwise inaccessible metal compounds. 


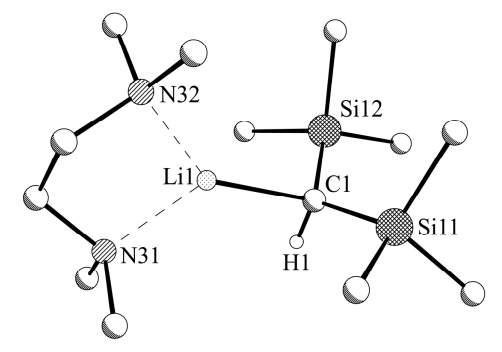

Figure 4. Molecular structure of $\mathrm{LiCH}\left(\mathrm{SiMe}_{3}\right)_{2}$-TMEDA, $\mathbf{1 b}$; only one of the two independent molecules in the asymmetric unit is shown. Selected hydrogen atoms and disordered units of minor occupancy are omitted for clarity.

This difference between short $\mathrm{Li}-\mathrm{C}$ distances for monomeric units and longer $\mathrm{Li}-\mathrm{C}$ distances in oligomers can be explained by the existence of two-center two-electron bonds for the monomeric compounds, while the bonds in oligomeric and polymeric compounds should be based on three-center two-electron bonds (linear or bent). Due to the one-sided interaction of the lithium with the bis(trimethylsilyl)methyl group, the $\left(\mathrm{Me}_{3} \mathrm{Si}\right)_{2} \mathrm{CH}$ unit shows a trigonal pyramidal arrangement of the trimethylsilyl groups and the hydrogen atom $\left(\mathrm{Si}-\mathrm{C}-\mathrm{Si} 123.25(10)^{\circ}\right.$ and $122.48(11)^{\circ}$; the sum of the $\mathrm{Si}-\mathrm{C}-\mathrm{Si}$ and two $\mathrm{H}-\mathrm{C}-\mathrm{Si}$ angles: $341.1^{\circ}$ and $341.0^{\circ}$ ). The two nitrogen atoms of the TMEDA coordinate the lithium atom (Li-N 2.054(6) and 2.071(9) $\AA$; 2.133(7) and 2.061(9) $\AA$ ) with an N-Li-N bite angle of $88.8(2)^{\circ}$ and $87.2(2)^{\circ}$.

According to X-ray crystallographic data the sodium compound 2a (Figure 5) organizes in the solid state as a polymeric chain along the crystallographic $b$-axis consisting of THF-coordinated 2 units with sodium oxygen-interactions (Na1-O1 2.375(3) $\AA$ ). The central carbon of the $\mathrm{CH}\left(\mathrm{SiMe}_{3}\right)_{2}$ group shows a roughly linear $\left(\mathrm{Na}-\mathrm{C}-\mathrm{Na} 159.30(18)^{\circ}\right)$ coordination by two sodium atoms with slightly different bond lengths (Na1-C1 2.778(4) $\AA$; Na1A-C1 2.657(4) $\AA$ ), leading to an approximately trigonal bipyramidal environment of the carbon atom. A very similar pattern of $\mathrm{Na}-\mathrm{C}$ distances was found in polymeric TMEDA-coordinated trimethylsilylmethylsodium with $\mathrm{Na}-\mathrm{C} 2.523 \AA$ and $2.530 \AA$ [8]. Additionally, the sodium atoms with a coordination number of $\mathrm{CN}=3$ are coordinated by the oxygen of a THF group, leading to an approximately trigonal planar environment (C1-Na1-C1A $130.74(6)^{\circ}$; C1-Na1-O1 $129.93(13)^{\circ}$; C1A-Na1-O1 $99.33(13)^{\circ}$; sum of angles: $360.0^{\circ}$ ) of the sodium atom. Overall, this results in a zigzag shape of the polymeric chain very similar to the structure of bis(trimethylsilyl)methylpotassium coordinated by THF [13] or the structure of parent 2. Compared to the latter, the additional interaction with the oxygen atom merely leads to the reduction of the $\mathrm{Na}-\mathrm{C}-\mathrm{Na}$ angle from $143^{\circ}$ in 2 to $130.74(6)^{\circ}$ in $\mathbf{2 a}$, and the change from a screw axis with a periodicity of four to a simple zigzag chain.

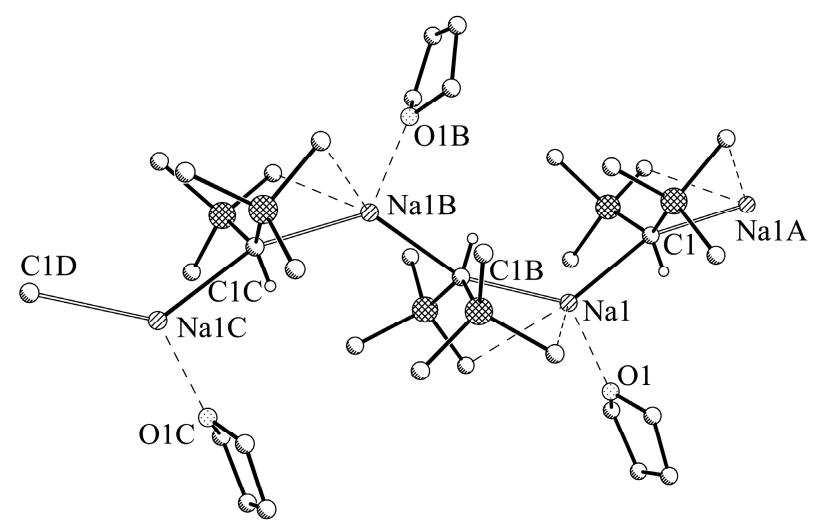

Figure 5. Trimeric section of polymeric $\left[\mathrm{NaCH}\left(\mathrm{SiMe}_{3}\right)_{2}-\mathrm{THF}\right]_{\infty}, \mathbf{2 a}$. Selected hydrogen atoms are omitted for clarity. Symmetry operator A: $-x+0.5, y-0.5,-z+0.5 ; \mathrm{B}:-x+0.5, y+0.5,-z+0.5$. 
The $\mathrm{CH}\left(\mathrm{SiMe}_{3}\right)_{2}$ moiety itself shows an approximate planar coordination of both $\mathrm{SiMe}_{3}$ groups and the hydrogen atom (Si11-C1-Si12 127.9 $(3)^{\circ}$, sum of the Si-C-Si and two H-C-Si angles: $359.3^{\circ}$ ). In addition, the methyl groups close to the $\mathrm{Na}$ atoms give rise to $\mathrm{Na} \cdots \mathrm{Me}$ contacts with short $\mathrm{Na}-\mathrm{C}$ distances (Na1-C111 3.104(5) $\AA$ and Na1-C123 2.961(5) $⿱$ ). Compound 2a is characterized by unusually short Na-H interactions with the hydrogen atom of the central C-H unit (Na-H 2.66 $\mathrm{A} / 2.70 \AA$ ) which are in a similar range as the corresponding $\mathrm{Na}-\mathrm{C}$ distances.

In contrast to the composition found through ${ }^{1} \mathrm{H}$ NMR spectroscopy with an equimolar ratio 2:TMEDA of 1:1, the crystals of compound $\mathbf{2 b}$ (Figure 6) isolated for X-ray crystallography show a ratio 2:TMEDA of 2:3. The compound can be described as dimer of TMEDA-coordinated monomers of 2 . The (symmetric) sodium atoms with a coordination number $\mathrm{CN}=4$ are in close contact with a $\mathrm{CH}\left(\mathrm{SiMe}_{3}\right)_{2}$ group (Na1-C1 2.520(2) $\AA$ ). The coordination sphere of the sodium is completed to a distorted tetrahedral environment by the three nitrogen atoms of two different

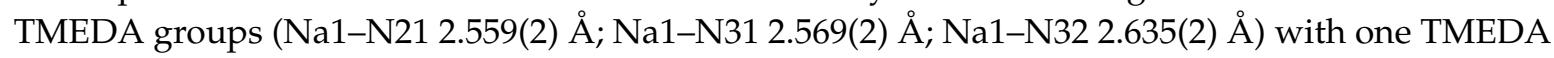
group bridging between the two symmetric monomeric units. A similar arrangement was found for TMEDA-coordinated trimethylsilyllithium [30]. The $\mathrm{CH}\left(\mathrm{SiMe}_{3}\right)_{2}$ unit shows a clear trigonal pyramidal arrangement of the $\mathrm{SiMe}_{3}$ groups and the hydrogen atom $\left(\mathrm{Si}-\mathrm{C}-\mathrm{Si} 120.91(7)^{\circ}\right.$; the sum of the $\mathrm{Si}-\mathrm{C}-\mathrm{Si}$ and two H-C-Si angles: $336.0^{\circ}$ ).

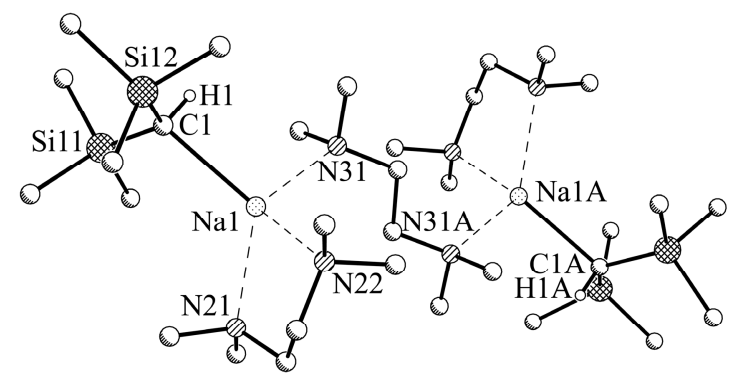

Figure 6. Molecular structure of $\left[\mathrm{NaCH}\left(\mathrm{SiMe}_{3}\right)_{2}\right]_{2}-3 \mathrm{TMEDA}, \mathbf{2 b}$. Selected hydrogen atoms and disordered units of minor occupancy are omitted for clarity. Symmetry operator A: $-x+1,-y+1,-z+2$.

\section{Materials and Methods}

\subsection{General Procedures}

$n$-Hexane, THF, and deuterated solvents were dried with potassium and distilled. TMEDA was dried with $\mathrm{CaH}_{2}$ and distilled. All synthetic work was carried out under an inert argon or nitrogen atmosphere using standard Schlenk and glove-box techniques. Bis(trimethylsilyl)methyllithium was prepared from bis(trimethylsilyl)bromomethane [31] and lithium in diethyl ether [9]. Bis(trimethylsilyl) methylsodium was synthesized following a literature procedure [11].

All ${ }^{1} \mathrm{H}$ single pulse (SP), ${ }^{1} \mathrm{H}$ correlation spectroscopy (COSY), ${ }^{1} \mathrm{H}_{-}-{ }^{13} \mathrm{C}$ heteronuclear single quantum coherence (HSQC), ${ }^{1} \mathrm{H}_{-}{ }^{13} \mathrm{C}$ heteronuclear multiple bond correlation (HMBC), ${ }^{13} \mathrm{C}$ with power gated decoupling scheme, ${ }^{7} \mathrm{Li} \mathrm{SP}$ and ${ }^{29} \mathrm{Si} \mathrm{NMR}$ experiments were performed at $294 \mathrm{~K}$ on a Bruker Avance DRX 400 NMR spectrometer (Bruker Biospin GmbH, Rheinstetten, Germany) operating at frequencies of $400.31 \mathrm{MHz}$ for ${ }^{1} \mathrm{H}, 100.66 \mathrm{MHz}$ for ${ }^{13} \mathrm{C}, 79.53 \mathrm{MHz}$ for ${ }^{29} \mathrm{Si}$ and $155.57 \mathrm{MHz}$ for ${ }^{7} \mathrm{Li}$ and equipped with a z-gradient dual channel inverse probe head with a gradient strength of $55 \mathrm{G} \cdot \mathrm{cm}^{-1}$. The ${ }^{1} \mathrm{H}$ spectra were referenced to the resonances of the remaining protons in the incompletely deuterated solvents $\left(\mathrm{C}_{6} \mathrm{D}_{6}\right.$, [D8]THF, and $\left.\mathrm{C}_{6} \mathrm{D}_{12}\right)$. The ${ }^{13} \mathrm{C}$ and ${ }^{29} \mathrm{Si}$ spectra were references to external TMS, while a $9.7 \mathrm{~m}$ solution of $\mathrm{LiCl}$ in $\mathrm{D}_{2} \mathrm{O}$ was used as an external reference for the ${ }^{7} \mathrm{Li}$ spectra.Stimulated echo sequence with bipolar gradient pulses and a longitudinal eddy current delay was used for the diffusion ordered spectroscopy (DOSY) experiments. The gradient strength was incremented in 16 steps from $2 \%$ to $95 \%$ of the maximum gradient strength. The diffusion time and the gradient pulse length for all measured samples were $200 \mathrm{~ms}$ and $2.8 \mathrm{~ms}$, respectively. After Fourier 
transformation and baseline correction, the diffusion dimension of the 2D DOSY spectra was processed using the Bruker Topspin 1.3 software package. The diffusion analysis was performed using the T1/T2 relaxation Topspin package. Melting points were measured on a Stuart Scientific SMP10 melting point apparatus (Cole-Parmer, Stone, UK), and Elemental analyses on an Elementar Vario EL Cube (Elementar Analysensysteme GmbH, Langenseibold, Germany). Microanalyses were carried out, but due to instability, oxidation/hydrolysis, desolvation and possibly silicon-carbide formation satisfactory elemental analysis could be obtained only for compound $\mathbf{1 b}$.

Single crystals were mounted in inert oil under a protective atmosphere by applying the X-Temp2 device [27]. Data for X-ray crystal structure determination were obtained with a Bruker SMART Apex II diffractometer (Bruker Corporation, Billerica, MA, USA) using Mo K $\alpha$ radiation $(\lambda=0.71073 \AA$ ) . All structures were refined to convergence against $F^{2}$ using programs from the SHELX family [32,33].

The cryoscopic measurements were prepared in the glove-box by placing a defined amount of $\mathbf{1}$ or $\mathbf{2}$ into a sample vial, which was placed into a Schlenk flask. After connecting the Schlenk flask to the Schlenk line, a defined amount of cyclohexane was added under an argon atmosphere. A calibrated Beckmann thermometer (Amarell GmbH \& Co. KG, Kreuzwertheim, Germany) was placed into the Schlenk flask using a using a Schott Gl 25 connection system (DWK Life Sciences GmbH, Mainz, Germany). An ice-bath was used to reach the necessary temperature.

\subsection{Syntheses}

\subsubsection{Experimental Procedure for $\left[\mathrm{LiCH}\left(\mathrm{SiMe}_{3}\right)_{2}-\mathrm{THF}\right](\mathbf{1 a})$}

Bis(trimethylsilyl)methyllithium $1(0.17 \mathrm{~g}, 1.0 \mathrm{mmol})$ was dissolved in $n$-hexane $(20 \mathrm{~mL})$, and THF (0.16 mL, $2.0 \mathrm{mmol}, 2 \mathrm{eq})$ was added under stirring. A portion of the solvent was removed under vacuum, and the solution was stored at RT to yield a crop of colorless blocks $(0.14 \mathrm{~g}, 52 \%$ yield $)$. ${ }^{1} \mathrm{H}$ NMR $\left(400 \mathrm{MHz}, 300 \mathrm{~K}, \mathrm{C}_{6} \mathrm{D}_{12}\right): \delta=-2.39$ (s, $\left.1 \mathrm{H}, \mathrm{CH}\right),-0.02$ (s, $18 \mathrm{H}, \mathrm{SiMe}$ ) $), 1.89(\mathrm{~m}, 4 \mathrm{H}, \beta-\mathrm{THF})$, $3.88\left(\mathrm{~m}, 4 \mathrm{H}, \alpha\right.$-THF) ppm. ${ }^{13} \mathrm{C}$ NMR $\left(100 \mathrm{MHz}, 300 \mathrm{~K}, \mathrm{C}_{6} \mathrm{D}_{12}\right): \delta=2.0(\mathrm{CH}), 5.7(\mathrm{SiMe}), 26.1(\beta-\mathrm{THF})$, $69.2(\alpha-\mathrm{THF})$ ppm. ${ }^{7} \mathrm{Li} \mathrm{NMR}\left(155 \mathrm{MHz}, 300 \mathrm{~K}, \mathrm{C}_{6} \mathrm{D}_{12}\right): 2.9 \mathrm{ppm} .{ }^{29} \mathrm{Si} \mathrm{NMR}\left(80 \mathrm{MHz}, 300 \mathrm{~K}, \mathrm{C}_{6} \mathrm{D}_{12}\right)$ : $-6.0\left(\mathrm{SiMe}_{3}\right)$ ppm. Melting point: $72{ }^{\circ} \mathrm{C}$.

\subsubsection{Experimental Procedure for $\left[\mathrm{LiCH}\left(\mathrm{SiMe}_{3}\right)_{2}-\mathrm{TMEDA}\right](\mathbf{1 b})$}

Bis(trimethylsilyl)methyllithium $1(0.17 \mathrm{~g}, 1.0 \mathrm{mmol})$ was dissolved in $n$-hexane $(20 \mathrm{~mL})$, and TMEDA $(0.16 \mathrm{~mL}, 1.05 \mathrm{mmol}, 1.05 \mathrm{eq})$ was added under stirring. A portion of the solvent was removed under vacuum, and the solution was stored at $6{ }^{\circ} \mathrm{C}$ to yield a crop of colorless platelets $(0.10 \mathrm{~g}, 34 \%$ yield). ${ }^{1} \mathrm{H}$ NMR $\left(400 \mathrm{MHz}, 300 \mathrm{~K}, \mathrm{C}_{6} \mathrm{D}_{12}\right): \delta=-2.05$ (s, $\left.1 \mathrm{H}, \mathrm{CH}\right),-0.10(\mathrm{~s}, 18 \mathrm{H}, \mathrm{SiMe}), 2.30(\mathrm{~s}, 12 \mathrm{H}$, Me-TMEDA), 2.37 (s, $4 \mathrm{H}, \mathrm{CH}_{2}$-TMEDA) ppm. ${ }^{13} \mathrm{C} \mathrm{NMR}\left(100 \mathrm{MHz}, 300 \mathrm{~K}, \mathrm{C}_{6} \mathrm{D}_{12}\right): \delta=2.3(\mathrm{CH}), 6.4$ $\left(\mathrm{SiMe}_{3}\right), 45.1$ (s, $\left.12 \mathrm{H}, \mathrm{Me}-\mathrm{TMEDA}\right), 57.3$ (s, $4 \mathrm{H}, \mathrm{CH}_{2}$-TMEDA) ppm. ${ }^{7} \mathrm{Li} \mathrm{NMR}\left(155 \mathrm{MHz}, 300 \mathrm{~K}, \mathrm{C}_{6} \mathrm{D}_{12}\right)$ : 3.1 ppm. ${ }^{29} \mathrm{Si} \mathrm{NMR}\left(80 \mathrm{MHz}, 300 \mathrm{~K}, \mathrm{C}_{6} \mathrm{D}_{12}\right)$ : -7.9 (SiMe $)$ ppm. Melting point: $58{ }^{\circ} \mathrm{C}$. Elemental analysis (\%) calcd. for $\mathrm{C}_{13} \mathrm{H}_{35} \mathrm{LiN}_{2} \mathrm{Si}_{2}(\mathrm{M}=282.54 \mathrm{~g} / \mathrm{mol}): \mathrm{C}, 55.26 ; \mathrm{H}, 12.49 ; \mathrm{N}, 9.92$; found: $\mathrm{C}, 54.69$; $\mathrm{H}, 13.54 ; \mathrm{N}, 10.08$.

\subsubsection{Experimental Procedure for $\left[\mathrm{NaCH}\left(\mathrm{SiMe}_{3}\right)_{2}-\mathrm{THF}\right](\mathbf{2 a})$}

Bis(trimethylsilyl)methyllithium 2 (0.07 g, $0.4 \mathrm{mmol})$ was dissolved in $n$-hexane $(5 \mathrm{~mL})$; THF $(0.07 \mathrm{~mL}, 0.9 \mathrm{mmol}, 2.2 \mathrm{eq})$ was added under stirring. A portion of the solvent was removed under vacuum, and the solution was stored at $-20^{\circ} \mathrm{C}$ to yield a crop of yellowish needles $(0.017 \mathrm{~g}, 17 \%$ yield $)$. The compound showed slow decomposition at room temperature. ${ }^{1} \mathrm{H}$ NMR $\left(400 \mathrm{MHz}, 300 \mathrm{~K}, \mathrm{C}_{6} \mathrm{D}_{12}\right)$ : $\delta=-2.28(\mathrm{~s}, 1 \mathrm{H}, \mathrm{CH}), 0.0(\mathrm{~s}, 18 \mathrm{H}, \mathrm{SiMe}), 1.83(\mathrm{~m}, 4 \mathrm{H}, \beta-\mathrm{THF}), 3.76(\mathrm{~m}, 4 \mathrm{H}, \alpha-\mathrm{THF}) \mathrm{ppm} .{ }^{13} \mathrm{C} \mathrm{NMR}$ $\left.\left(100 \mathrm{MHz}, 300 \mathrm{~K}, \mathrm{C}_{6} \mathrm{D}_{12}\right): \delta=1.1(\mathrm{CH}), 6.7(\mathrm{SiMe})_{3}\right), 27.0(\beta-\mathrm{THF}), 68.7(\alpha-\mathrm{THF})$ ppm. ${ }^{29} \mathrm{Si} \mathrm{NMR}(80 \mathrm{MHz}$, $\left.300 \mathrm{~K}, \mathrm{C}_{6} \mathrm{D}_{12}\right):-10.1\left(\mathrm{SiMe}_{3}\right) \mathrm{ppm}$. 


\subsubsection{Experimental Procedure for $\left[\mathrm{NaCH}\left(\mathrm{SiMe}_{3}\right)_{2}-\mathrm{TMEDA}\right](\mathbf{2 b})$}

Bis(trimethylsilyl)methyllithium $2(0.18 \mathrm{~g}, 1.0 \mathrm{mmol})$ was dissolved in $n$-hexane $(5 \mathrm{~mL})$, and TMEDA $(0.30 \mathrm{~mL}, 2.0 \mathrm{mmol}, 2 \mathrm{eq})$ was added under stirring. A portion of the solvent was removed under vacuum, and the solution was stored $-20{ }^{\circ} \mathrm{C}$ to yield a crop of large colorless blocks. ${ }^{1} \mathrm{H}$ NMR $\left(400 \mathrm{MHz}, 300 \mathrm{~K}, \mathrm{C}_{6} \mathrm{D}_{12}\right): \delta=-2.04(\mathrm{~s}, 1 \mathrm{H}, \mathrm{CH}),-0.08$ (s, $\left.18 \mathrm{H}, \mathrm{SiMe} 3\right), 2.25$ (s, $\left.12 \mathrm{H}, \mathrm{Me}-\mathrm{TMEDA}\right)$, $2.34\left(\mathrm{~s}, 4 \mathrm{H}, \mathrm{CH}_{2}\right.$-TMEDA) ppm. ${ }^{13} \mathrm{C}$ NMR $\left(100 \mathrm{MHz}, 300 \mathrm{~K}, \mathrm{C}_{6} \mathrm{D}_{12}\right): \delta=1.0(\mathrm{CH}), 6.7(\mathrm{SiMe}), 46.2(\mathrm{~s}$, $12 \mathrm{H}, \mathrm{Me}-\mathrm{TMEDA}), 58.0$ (s, $4 \mathrm{H}, \mathrm{CH}_{2}$-TMEDA) ppm. ${ }^{29} \mathrm{Si} \mathrm{NMR}\left(80 \mathrm{MHz}, 300 \mathrm{~K}, \mathrm{C}_{6} \mathrm{D}_{12}\right):-8.5\left(\mathrm{SiMe}_{3}\right)$ ppm. Melting point: $<0^{\circ} \mathrm{C}$.

\section{Conclusions}

In summary, we used cryoscopy and NMR DOSY measurements to examine solutions of bis(trimethylsilyl)methyllithium and -sodium in cyclohexane, which form polymeric chains in solid state. Bis(trimethylsilyl)methyllithium forms dimers in solution independent of its concentration. In diluted solutions, bis(trimethylsilyl)methylsodium exists as tetrameric aggregates, and more concentrated solutions reveal hexameric aggregates. This behavior reflects the high steric demand of the bis(trimethylsilyl)methyl group, which does not allow interactions with more than two lithium atoms. In the case of sodium compounds, higher flexibility results from the longer $\mathrm{Na}-\mathrm{C}$ interactions and the two bulky silyl groups also contribute to the stabilization of the negative charge. This is demonstrated by the low reactivity/basicity towards THF and TMEDA, which form stable complexes with both bis(trimethylsilyl)methyllithium and -sodium. THF as a strong, but not very bulky, donor leads to an additional coordination of the corresponding lithium or sodium atom, without decreasing the numbers of alkyl-metal interactions (dimer or polymer). For both the corresponding lithium and sodium compounds, TMEDA achieves the dissociation of the existing oligomers to monomeric units by blocking interactions with other alkyllithium or -sodium units, respectively. The dimeric structure found for THF-coordinated bis(trimethylsilyl)methyllithium could be considered as a representation of the uncoordinated compound in cyclohexane solution, which was identified as dimeric. However, using coordinating ligands in combination with (trimethylsilyl)methylsodium leads to the formation monomers or dimers. This is in contrast to the cage-shaped molecules expected for soluble larger aggregates such as tetramers and hexamers, which could be identified in cyclohexane solution.

Supplementary Materials: The following are available online at www.mdpi.com/2304-6740/5/2/39/s1, Table S1: Preparation of cryoscopic measurements in cyclohexane and results, Figures S1-S21: ${ }^{1} \mathrm{H},{ }^{13} \mathrm{C},{ }^{7} \mathrm{Li}$, and ${ }^{29} \mathrm{Si} \mathrm{NMR}$ spectra of $\mathbf{1}$ and $\mathbf{2}$ in $\mathrm{C}_{6} \mathrm{D}_{6}$, [D8]THF, and $\mathrm{C}_{6} \mathrm{D}_{12}$; Figures S22-S35: ${ }^{1} \mathrm{H},{ }^{13} \mathrm{C},{ }^{7} \mathrm{Li}$, and ${ }^{29} \mathrm{Si} \mathrm{NMR}$ spectra of $\mathbf{1 a}, \mathbf{b}$ and $\mathbf{2} \mathbf{a}, \mathbf{b}$ in $\mathrm{C}_{6} \mathrm{D}_{12}$, Figures S36-S39: displacement ellipsoid diagrams of $\mathbf{1} \mathbf{a}, \mathbf{b}$ and $\mathbf{2} \mathbf{a}, \mathbf{b}$.

Acknowledgments: This work was supported by Internal University Research Funding of the University of Mainz. We thank Karl Klinkhammer for the generous support of this work and helpful discussions, Dieter Schollmeyer and Regine Jung-Pothmann for X-ray crystallographic measurements, and Maximilian Kaiser for help with the cryoscopic measurements.

Author Contributions: Jan Klett conceived and designed the experiments; Jan Klett and Markus von Pilgrim performed the experiments; Jan Klett and Mihail Mondeshki analyzed the data; Jan Klett wrote the manuscript.

Conflicts of Interest: The authors declare no conflict of interest.

\section{Appendix A}

The structures cited can be found in the Cambridge Crystallographic Data Centre under the following CSD-Refcodes: 1, CIMVUP; 1-PMDETA, BIYXOW; 2, PETXUH; [THF-KCH$\left.\left(\mathrm{SiMe}_{3}\right)_{2}\right]_{\infty}$, MURHIQ; $\left[t \mathrm{BuOMe}-\mathrm{KCH}\left(\mathrm{SiMe}_{3}\right)_{2}\right]_{\infty}$, QUHNIQ; (PMDETA $)_{2}-\left(\mathrm{KCH}\left(\mathrm{SiMe}_{3}\right)_{2}\right)_{4}, \quad$ QUHNOW; $(\mathrm{TMEDA})_{3}-\left(\mathrm{NaCH}_{2} \mathrm{SiMe}_{3}\right)_{4}, \mathrm{OSESEL} ;(\mathrm{TMEDA})_{3}-\left(\mathrm{LiSiMe}_{3}\right)_{2}, \mathrm{BIJMAI}$. 


\section{References}

1. Clayden, J. Organolithiums: Selectivity for Synthesis; Elsevier Oxford: Kidlington, UK, 2002.

2. Schlosser, M. Organometallics in Synthesis-A Manual, 2nd ed.; John Wiley \& Sons, Inc.: Hoboken, NJ, USA, 2013.

3. Gessner, V.H.; Däschlein, C.; Strohmann, C. Structure formation principles and reactivity of organolithium compounds. Chemistry 2009, 15, 3320-3334. [CrossRef] [PubMed]

4. Seiferth, D. Alkyl and Aryl derivatives of the Alkali metals: Strong bases and reactive nucleophiles. 2. Wilhelm Schlenk's Organoalkali-metal chemistry. The metal displacement and the transmetalation reactions. metalation of weakly acidic hydrocarbons. Superbases. Organometallics 2009, 28, 2-33. [CrossRef]

5. Harrison-Marchand, A.; Mongin, F. Mixed AggregAte (MAA): A single concept for all dipolar organometallic aggregates. 1. Structural data. Chem. Rev. 2013, 113, 7470-7562. [CrossRef] [PubMed]

6. Reich, H.J. Role of organolithium aggregates and mixed aggregates in organolithium mechanisms. Chem. Rev. 2013, 113, 7130-7178. [CrossRef] [PubMed]

7. Collum, D.B. Is $N, N, N^{\prime}, N^{\prime}$-tetramethylethylenediamine a good ligand for lithium? Acc. Chem. Res. 1992, 25, 448-454. [CrossRef]

8. Clegg, W.; Conway, B.; Kennedy, A.R.; Klett, J.; Mulvey, R.E.; Russo, L. Synthesis and structures of [(Trimethylsilyl)methyl]sodium and -potassium with bi- and tridentate $\mathrm{N}$-donor ligands. Eur. J. Inorg. Chem. 2011, 721-726. [CrossRef]

9. Davidson, P.J.; Harris, D.H.; Lappert, M.F. Subvalent Group 4B metal alkyls and amides. Part I. The synthesis and physical properties of kinetically stable bis[bis(trimethylsilyl)methyl]-germanium(II), -tin(II), and -lead(II). J. Chem. Soc. Dalton Trans. 1976, 21, 2268-2274. [CrossRef]

10. Atwood, J.L.; Fjeldberg, T.; Lappert, M.F.; Luong-Thi, N.T.; Shakir, R.; Thorne, A.J. Molecular structures of bis(trimethylsilyl)methyl-lithium $\left[(\mathrm{LiR})_{n}, \mathrm{R}=\mathrm{CH}\left(\mathrm{SiMe}_{3}\right)_{2}\right]$ in the vapour (gas-phase electron diffraction: A monomer, $n=1$ ) and the crystal (X-Ray: A polymer, $n=\infty)$. J. Chem. Soc. Chem. Commun. 1984, 17, 1163-1165. [CrossRef]

11. Hitchcock, P.B.; Lappert, M.F.; Leung, W.-P.; Liu, D.S.; Tian, S. Synthesis and structures of the heavier alkali metal alkyls; the X-ray structures of $[\mathrm{Na}(\mu-\mathrm{R})]_{\infty}$, and $[\mathrm{Rb}(\mu-\mathrm{R})(\text { pmdeta })]_{2}\left[\mathrm{R}=\mathrm{CH}\left(\mathrm{SiMe}_{3}\right)_{2}\right.$, pmdeta $=\left(\mathrm{Me}_{2} \mathrm{NCH}_{2} \mathrm{CH}_{2}\right)_{2} \mathrm{NMe}$. J. Chem. Soc. Chem. Commun. 1993, 18, 1386-1387. [CrossRef]

12. Pakuro, N.I.; Arest-Yakubovich, A.A.; Shcheglova, L.V.; Petrovsky, P.V.; Chekulaeva, L.A. NMR spectra of a hydrocarbon-soluble organosodium compound and its lithium analogs. Rus. Chem. Bull. 1996, 45, 838-840. [CrossRef]

13. Hitchcock, P.B.; Khvostov, A.V.; Lappert, M.F. Synthesis and structures of crystalline bis(trimethylsilyl) methanide complexes of potassium, calcium and ytterbium. J. Organomet. Chem. 2002, 663, 263-268. [CrossRef]

14. Boesveld, W.M.; Hitchcock, P.B.; Lappert, M.F.; Liu, D.-S.; Tian, S. Synthesis and structures of the crystalline heavier alkali metal alkyls: X-ray structures of $\left[\mathrm{K}(\mu-\mathrm{R})\left\{\mathrm{O}(\mathrm{Me}) \mathrm{Bu}^{\mathrm{t}}\right\}\right]_{\infty},\left[(\right.$ pmdeta $) \mathrm{K}(\mu-\mathrm{R}) \mathrm{K}(\mu-\mathrm{R})_{2}$ $\mathrm{K}(\mu-\mathrm{R}) \mathrm{K}($ pmdeta $)]$, and $[\mathrm{Cs}(\mu-\mathrm{R})(\text { tmeda })]_{\infty}\left(\mathrm{R}=\mathrm{CH}\left(\mathrm{SiMe}_{3}\right)_{2}\right)$. Organometallics 2000, 19, 4030-4035. [CrossRef]

15. Lewis, H.L.; Brown, T.B. Association of alkyllithium compounds in hydrocarbon media. Alkyllithium-base interactions. J. Am. Chem. Soc. 1970, 92, 4664-4670. [CrossRef]

16. Lappert, M.F.; Engelhardt, L.M.; Raston, C.L.; White, A.H. Synthesis of $\left[\mathrm{Li}\left(\mathrm{CH}_{2} \mathrm{SiMe}_{3}\right)(\mathrm{pmdeta})\right]$ and the crystalline monomeric bulky alkyl-lithium complexes[LiR(tmeda)]and [ $\mathrm{LiR}$ (pmdeta)][R $\left.=\mathrm{CH}\left(\mathrm{SiMe}_{3}\right)_{2}\right]$; $X$-ray crystal structure of $\left[\mathrm{Li}\left\{\mathrm{CH}\left(\mathrm{SiMe}_{3}\right)_{2}\right\}\right.$ (pmdeta) $]\left\{\right.$ tmeda $=\mathrm{Me}_{2} \mathrm{NCH}_{2} \mathrm{CH}_{2} \mathrm{NMe}_{2}$, pmdeta $=\mathrm{Me}_{2} \mathrm{~N}\left[\mathrm{CH}_{2}\right]_{2}$ $\left.\mathrm{N}(\mathrm{Me})\left[\mathrm{CH}_{2}\right]_{2} \mathrm{NMe}_{2}\right\}$. J. Chem. Soc. Chem. Commun. 1982, 1323-1324. [CrossRef]

17. Lochmann, L.; Janata, M. 50 years of superbases made from organolithium compounds and heavier alkali metal alkoxides. Cent. Eur. J. Chem. 2014, 12, 537-548. [CrossRef]

18. Unkelbach, C.; O'Shea, D.F.; Strohmann, C. Insights into the metalation of benzene and toluene by Schlosser's base: A superbasic cluster comprising PhK, PhLi, and tBuOLi. Angew. Chem. Int. Ed. 2014, 53, 553-556. [CrossRef] [PubMed]

19. Benrath, P.; Kaiser, M.; Limbach, T.; Mondeshki, M.; Klett, J. Combining neopentyllithium with potassium tert-butoxide: Formation of an alkane-soluble lochmann-schlosser superbase. Angew. Chem. Int. Ed. 2016, 55, 10886-10889. [CrossRef] [PubMed] 
20. Stokes, R.H.; Tomlins, R.P. Thermodynamic functions of melting for cyclohexane. J. Chem. Thermodyn. 1974, 6, 379-386. [CrossRef]

21. Armstrong, D.R.; Barr, D.; Clegg, W.; Mulvey, R.E.; Reed, D.; Snaith, D.; Wade, K. The laddering principle in lithium amide chemistry: the crystal and molecular structure of the pyrrolididolithium adduct $\left[\mathrm{H}_{2} \mathrm{C}\left(\mathrm{CH}_{2}\right)_{3} \mathrm{NLi}\right]_{3} \mathrm{MeN}\left(\mathrm{CH}_{2} \mathrm{CH}_{2} \mathrm{NMe}_{2}\right)_{2}$. J. Chem. Soc. Chem. Commun. 1986, 11, 869-870. [CrossRef]

22. Bond, A.D. Ring-laddering and ring-stacking: Unifying concepts in the structural chemistry of organic ammonium halides. Cryst. Growth Des. 2005, 5, 755-771. [CrossRef]

23. Hevia, E.; Kennedy, A.R.; Mulvey, R.E.; Ramsay, D.L.; Robertson, S.D. Concealed cyclotrimeric polymorph of lithium 2,2,6,6-tetramethylpiperidide unconcealed: X-Ray crystallographic and NMR spectroscopic studies. Chem. Eur. J. 2013, 19, 1521-3765. [CrossRef] [PubMed]

24. Fraenkel, G.; Chow, A.; Winchester, W.R. Structure and dynamic behavior of solvated neopentyllithium monomers, dimers, and tetramers: Proton, carbon-13 and lithium-6 NMR. J. Am. Chem. Soc. 1990, 112, 6190-6198. [CrossRef]

25. Neufeld, R.; John, M.; Stalke, D. The donor-base-free aggregation of lithium diisopropyl amide in hydrocarbons revealed by a DOSY method. Angew. Chem. Int. Ed. 2015, 54, 6994-6998. [CrossRef] [PubMed]

26. Kottke, T.; Lagow, R.J. Isolation and structure analysis of neohexyllithium generated by ether cleavage: Primary and secondary coordination in alkyllithium aggregates. Organometallics 1997, 16, 789-792. [CrossRef]

27. Kottke, T.; Stalke, D. Crystal handling at low temperatures. J. Appl. Cryst. 1993, 26, 615-619. [CrossRef]

28. The Cambridge Crystallographic Data Centre. Available online: http://www.ccdc.cam.ac.uk/conts/ retrieving.html (accessed on 8 May 2017).

29. Engelhardt, L.M.; Jolly, B.S.; Junk, P.C.; Raston, C.L.; Skelton, B.W.; White, A.H. Highly hindered amido-lithium and amido-magnesium complexes. Crystal-structures of $\left[\mathrm{Li}\left(\mathrm{Mu}-\mathrm{N}\left(\mathrm{SiMe}_{3}\right)_{2}\right)\right.$ (tetrahydrofuran) $]_{2}$ and $\left[\mathrm{MgBus}\left(\mathrm{Mu}-\mathrm{N}\left(\mathrm{SiMe}_{3}\right)_{2}\right)\right]_{2}$. Aust. J. Chem. 1986, 39, 1337-1345. [CrossRef]

30. Teclé, B.; Ilsley, W.H.; Oliver, J.P. Metal-silicon bonded compounds. 16. The structure of $\left(\mathrm{LiSiMe}_{3}\right)_{2}$. $\left(\mathrm{Me}_{2} \mathrm{NCH}_{2} \mathrm{CH}_{2} \mathrm{NMe}_{2}\right)_{3}$, a highly reactive silylating agent. Organometallics 1982, 1, 875-877. [CrossRef]

31. Wiberg, N.; Wagner, G. Auf dem Wege zu einem stabilen Silaethen: Sterisch überladene Trisilylmethane $t \mathrm{Bu}_{2} \mathrm{SiX}-\mathrm{CY}\left(\mathrm{SiMe}_{3}\right)_{2}(\mathrm{X}, \mathrm{Y}=\mathrm{H}, \mathrm{Hal}, \mathrm{Li})$. Eur. J. Inorg. Chem. 1986, 119, 1455-1466. [CrossRef]

32. Sheldrick, G.M. A short history of SHELX. Acta Cryst. 2008, 64, 112-122. [CrossRef] [PubMed]

33. Müller, P.; Herbst-Irmer, R.; Spek, A.L.; Schneider, T.R.; Sawaya, M.R. Crystal Structure RefinementA Crystallographer's Guide to SHELXL; Oxford University Press: Oxford, UK, 2006. 